\title{
The Causal Relationship Between Institutions and Economic Growth: An Empirical Investigation for Pakistan Economy
}

\author{
Danish Ahmed Siddiqui \\ Karachi University, Pakistan \\ Qazi Masood Ahmed \\ Institute of Business Administration, Pakistan
}

Received: November 13, 2018 Accepted: March 19, 2019 Published: March 21, 2019

doi:10.5296/ieb.v5i1.13918

URL: https://doi.org/10.5296/ieb.v5i1.13918

\begin{abstract}
This paper investigates relationship between institutional quality and economic performance in Pakistan using the Johansen-Juselius cointegration technique and the Granger causality test. The study results indicate that Institutions and growth are cointegrated and thus exhibit a reliable long run relationship. The Granger causality test findings indicate that the causality between Institutions and growth is uni-directional.

However, there is no short run causality from Institutions to growth and vice versa. Therefore, as a policy implication that institutional quality may cause to the sustainable increase in country's income in the long run, and success of any policy could be influenced by the soundness of institutions.
\end{abstract}

Keywords: Institutions, growth, Cointegration, Causality, Pakistan, rent seeking 


\section{Introduction}

Exploring the relationship between economic performance and the quality of domestic institutions has been a major area of interest. The better quality of institutions has a positive and significant effect on growth and human development and this effect is more vehement for long term growth than short term. The role of regulatory institutional capacity also play important role for the cross-country variations in economic growth through positive impact on total factor productivity. The causality between institutions and economic performance is also important issue and studies shows better institutions leads to a higher income rather than causation being in the opposite direction. Some studies find that the quality of governance and institutions is important in explaining the higher rates of investment through improving the climate for capital creation. Other studies reiterated institutional roles in improving international capital flows in particular FDI and portfolio investment. However most of the empirical evidence about the relationship between institutions and growth are based on crosssectional and cross-country analysis. Quite apart from general methodological flaws relating to model specification and econometric procedure, there are two fundamental limitations that make results from any cross-country study on the subject rather dubious. First, cross-country regression analysis is based on the implicit assumption of "homogeneity" in the observed relationship across countries. This is very restrictive assumption. Secondly, given vast difference among countries with respect to nature and quality of data, cross-country comparison is fraught with danger. These considerations point a need for undertaking econometric analysis of individual countries over time in order to build a sound empirical foundation for informing the policy debate. There is a rich literature on Solow growth model, extended growth model, endogenous growth model and extended endogenous growth model. This literature assumes transmission mechanism, distributive policies and institutions, are working properly and income is converging to high level. However, in developing countries such as Pakistan, this assumption is may not be valid and could be one of the most important reasons for low productivity and skewed income distribution.

The present study makes an early attempt to test empirically the role of institution on economic development of Pakistan. However, there is compelling evidence that many macroeconomics time series are non-stationary and as a result, OLS estimates using these data may produce spurious results. Although by now there exist well-developed techniques for handling non-stationary time series data. So far, no attempt has yet been made in Pakistan to study the long run causal relationship between institutions and economic performance by using well developed econometric techniques. This study employ Johansen-Juselius cointegration technique and the Granger causality test to examines the long run causal relationship between institutions and economic performance on annual data for Pakistan economy over the period 1984-2006. Earlier studies use data bases and indices which cover one or few aspects of the institutional capacity. For this paper we develop a comprehensive index of "institutionalized social technologies" which is built on theoretical framework of contract and predatory theories set by North (1981). This index is made up of Risk reducing technologies based on contract theory and Anti-Rent seeking technologies based on predatory theory of state. The plan of the paper is as follows: Section 2 covers review of literature, Section 3 presents an overview of quality of institutions in Pakistan; In Section 4, presents the 
model and econometric techniques and data Description; Section 5 presents and analyzes the empirical findings. And Section 6 presents a concluding summary.

\section{Review of Literature}

North (1990) defines institutions as the rules of the game in a society or, more formally, "the humanly devised constraints that shape human interaction". These rules of game can be in form of formal institutions like laws and regulations or informal ones which assimilated to culture Tabellini (2005) or social capital Putnam at al. (1993). Some institutions lowers transaction cost thereby result in innovation and productivity whereas other institutional features impedes information flow, raising information costs and eroding the gains from information, and limit entrepreneurial activity. Examples of institutions that stunt economic growth include government, police and/or court corruption, excessive taxation and/or regulation, unstable and/or inconsistent monetary and fiscal policy. (Frye \& Shleifer, 1997; Johnson, Kaufmann, \& Zoido-Lobaton 1998; Shleifer \& Vishney 1993, 1994; Soto, 1989, 2000; Rodrik at al., 2003, 2004; Easterly \& Levine, 2002; Kaufmann \& Kraay, 2002; Kaufmann, Kraay, \& Mastruzzi 2005; Knack \& Keefer, 1995; Mauro, 1995; Meon \& Sekkat, 2004; Barro, 1997, 2000; Sachs \& Warner, 1995). On distinguishing between kinds of institutions, North (1981) proposes two theories, a "contract theory" of the state and a "predatory theory" of the state. According to the first theory, the state and associated institutions provide the legal framework that enables private contracts to facilitate economic transactions hence reducing transaction costs. According to the second, the state is an instrument for transferring resources from one group to another.

Neoclassical growth modelling Solow (1956) predicted economies move toward their steadystate growth path which means that in the long run, income per capita levels will converge. However, lack of empirical support for convergence has presented a major challenge to these models. A more refined endogenous growth theory by Romer (1986) and Lucas (1988) and its empirics provides the evidence of ,conditional ${ }^{\text {lece }}$ convergence, where convergence is conditional on factors some of which are related to institutions. This is explained by new growth theories as "knowledge spillovers" assumption whereby any sector in less advanced countries can catch-up with the current technological frontier whenever it "innovates". The term "innovation" also refers to the adaptation of technologies which in turn depends upon the institutional arrangements. As argued by North and Thomas (1973), that far from being exogenous, technological changes crucially depend just on the prevailing institutions through their impact on incentives and transaction costs: it is these that largely determine how fast, if at all, technological changes will actually progress.

Institutions contributes to growth and development by reducing risk of doing business thus preventing diversion of resources and by preventing predatory rent seeking activities thereby diverting resource towards innovation. A society free of diversion, productive units are rewarded by the full amount of their production and individual units do not need to invest resources in avoiding diversion. In particular (Acemoglu et al., 2001, 2002, 2005) show that quality of institutions have a more important effect on long term growth than on short term one. Jalilian et al. (2007) emphasises the role of regulatory institutional capacity in accounting for cross-country variations in economic growth Méon and Weill (2006), Olson et al. (1998) find evidence suggesting that institutional factors are strongly related to total 
factor productivity. As productivity growth is higher in countries with better institutions and quality of governance. With regards to causal effect between institutions and economic performance, studies (Acemoglu, Johnson, \& Robinson 2000; Olson et al., 1998; Rodrik et al., 2004; Kauffman et al., 2005), indicates indicate that a better institutions leads to a higher income rather than causation being in the opposite direction. In particular Kauffman suggests that a one standard deviation improvement in governance institutions leads to a two to threefold difference in income levels in the long run. Acemogu and Johnson (2005) who attempted to distinguish between anti-rent seeking institutions and risk-reducing institutions, as they termed them as "property rights" and "contracting" institutions respectively. They found strong support for the importance of anti-rent seeking institutions on economic outcome but In contrast, indicate that the role of risk reducing institutions is more limited. The reason they give to this fact is, in absence of formal risk reducing institutions contracting institutions, the gap is filled by private alternative institutional arrangement. Like in earlier times when formal institutions of courts and police don't exist or ineffective, people then resort to dwell in groups where contracts are honoured through informal pressure and risk of expulsion from group. Hence their rights are secured in other ways. In contrast, protection from rent seeking behaviour relates to the relationship between the state and the citizens. When the state have major problems of corruption, inefficiency or no checks on the state, on politicians, and on elites, individuals don't have a level playing fields and adds to uncertainty. In this case, they are also unable to enter into private arrangements to circumvent these problems. In regional context, Fernandes and Kraay (2007) employing firm level data found the similar evidence that firms in the South Asian countries are able to circumvent failures in formal "contracting institutions", by resorting frequently to informal channels such as belonging to a business association. Some studies find that the quality of governance and institutions is important in explaining the rates of investment, as they suggested they effect economic performance through improving the climate for capital creation (Kirkpatrick, Parker, \& Zhang 2006; World Bank, 2003). Other studies reiterated institutional roles in improving international capital flows in particular FDI (Reisen \& De Soto, 2001; Smarzynska $\&$ Wei, 2000). And portfolio investment Gelos and Wei (2002)

A number of studies have made attempts to examine institutions in Pakistan as well in south Asian region. Mahbub ul Haq Human Development Centre (1999), Ahmed (2001) illustrated that institutions appears to be a significant problem in South Asia. Specially in Pakistan, institutional decay has led to poor governance, which has resulted in ad hoc policy-making. Instability and unpredictability has discouraged long-term investment and encouraged lobbying, corruption, and misuse of power, resulting in frustration and dysfunctional behaviour [For details, see DRI/McGraw-Hill (1998)]. [Hussain (1999)]. Asserts weak institutions have been used by èlite to extract rents in Pakistan. Institutional impact on poverty is explored in Pakistan (1999), Hassan (2002) Haq and Zia (2009), which shows institutions are negatively and significantly correlated with poverty, hence weak institutions to increase in poverty in Pakistan. However in contrast to the popular notion, Studies like Shafique and Haq (2006) based on world bank's governance indicators, find weak institutions do improve welfare of the society but it has negative influence on GDP growth rate. At another place, Fernandes and Kraay (2007) and Easterly (2003) in a study suggest that 
Pakistan have per capita incomes that are considerably higher than their very weak institutional performance would suggest based on average cross-country relationships.

\section{Overview of quality of institutions and economic growth in Pakistan}

We take index of institutionalized social technology, as well as its sub indices of Risk reducing technologies and Anti-rent seeking technologies for measurement of institutional quality. Risk reducing technology removes information asymmetry, creates mutual trust and hence decreases the risk of creating long term business relationships. It re-price contravention activities through increasing risk of getting caught. Anti-Rent seeking technologies plugs in predatory opportunities that arise due to gaps or loopholes in ineffective or week institutions, creating rents for controlling agents betting them higher return than though innovation hence is making society moves from innovative to rent seeking activities. This index specially focuses on technologies which helps curb the rent seeking opportunity arising from institutions, policies and political system. Table 1 focuses on periodic trends in institutional quality and growth. Over all institutional indicators fairly remain stable. They witness stable increase in periods of 1984 to 1999. Especially 1996-99 periods witnessed sharp increase in institutional quality. But afterwards, institutional index saw a sharp decline but again saw some improvements in later periods. On the political front, democratic era of 1988 to1999 saw a considerably higher institutional quality index then era govern by military dictatorships. Era of Transition to civilian democracy in 1988 witnessed sharp increase of about $19 \%$ in institutional quality especially anti-rent seeking technologies increases by about $55 \%$, while Era followed by military takeover after 1999 saw a sharp decline of about $31 \%$ in institutional quality. This trend can also be witnessed from Figure 1. Hence strong political institutions do produce a huge impact of other social institutions in the country and reforming and strengthening the political institutions become pivotal in economic and social development. On the other hand, growth in economy measured by real GDP per capita, witnessed a stable increase over the years. However, comparatively higher growth was witnessed in era of 1984- 91. In era of 90s, income level became fairly stable, and it sharply picked up later in 2000-06 period (Figure 2) Here the overall trend indicate authoritarian rule have comparatively higher growth whereas a lower institutional quality. The similar assessment is made by SPDC (2000), which shows that while governments under authoritarian rule in Pakistan were good for economic growth, they were not necessarily as successful in improving human endowment.

Table 1. Average Periodic Trend in institutional quality and growth

\begin{tabular}{lllll}
\hline obs & RGDPPC & IIST & RI & SII \\
\hline $\mathbf{1 9 8 4 - 8 7}$ & 2163.99 & 0.456977956 & 0.412333333 & 0.501622578 \\
$\mathbf{1 9 8 8 - 9 1}$ & 2418.43 & 0.543300359 & 0.6415 & 0.445100719 \\
$\mathbf{1 9 9 2 - 9 5}$ & 2574.73 & 0.54365293 & 0.570125 & 0.517180861 \\
$\mathbf{1 9 9 6 - 9 9}$ & 2680.8925 & 0.630186855 & 0.5821875 & 0.67818621 \\
\hline
\end{tabular}




\begin{tabular}{lllll}
$\mathbf{2 0 0 0 - 0 3}$ & 2788.5375 & 0.434945959 & 0.407270833 & 0.462621085 \\
$\mathbf{2 0 0 4 - 0 6}$ & 3247.29 & 0.448225958 & 0.396166667 & 0.500285249 \\
\hline
\end{tabular}

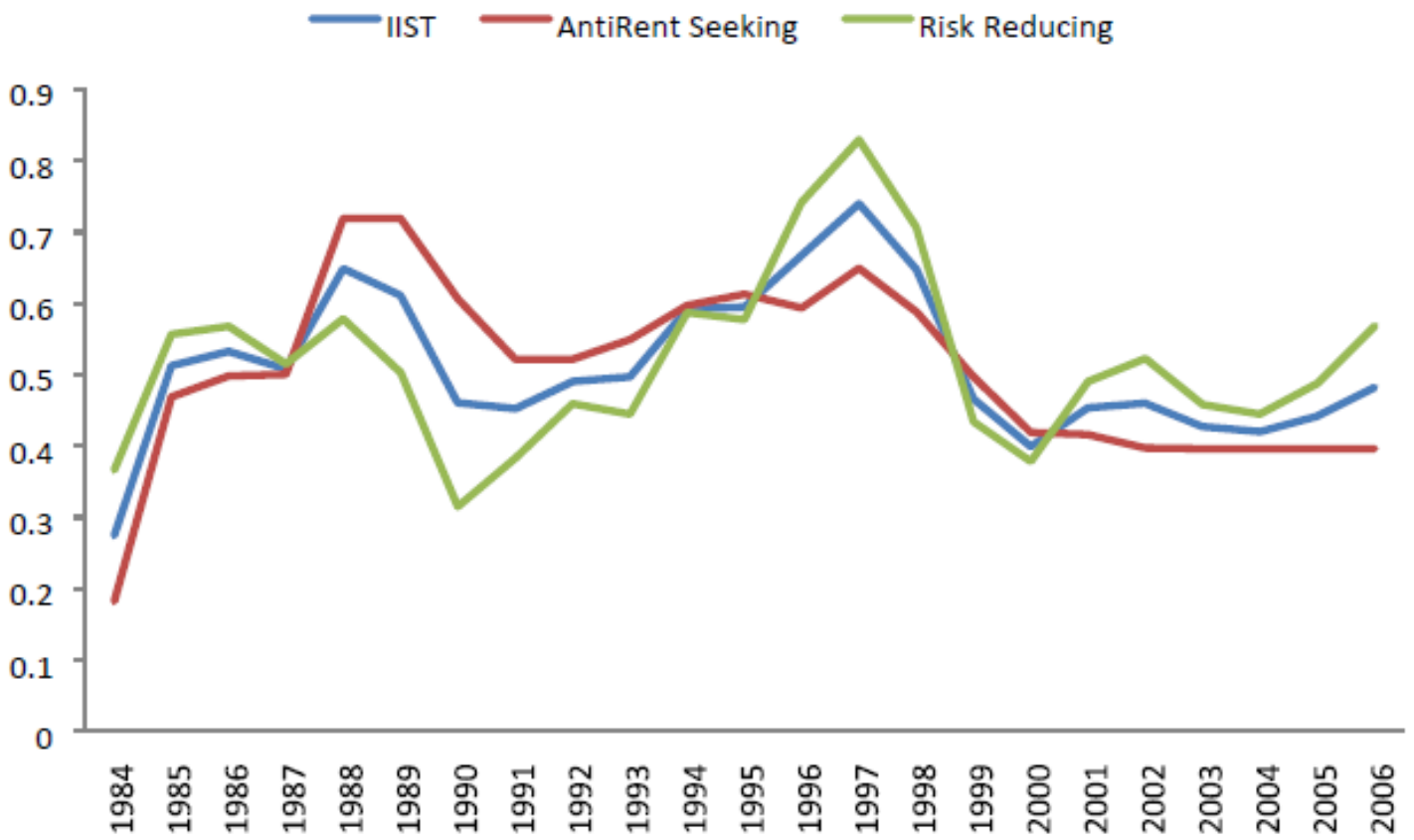

Figure 1. Institutionalized social technologies

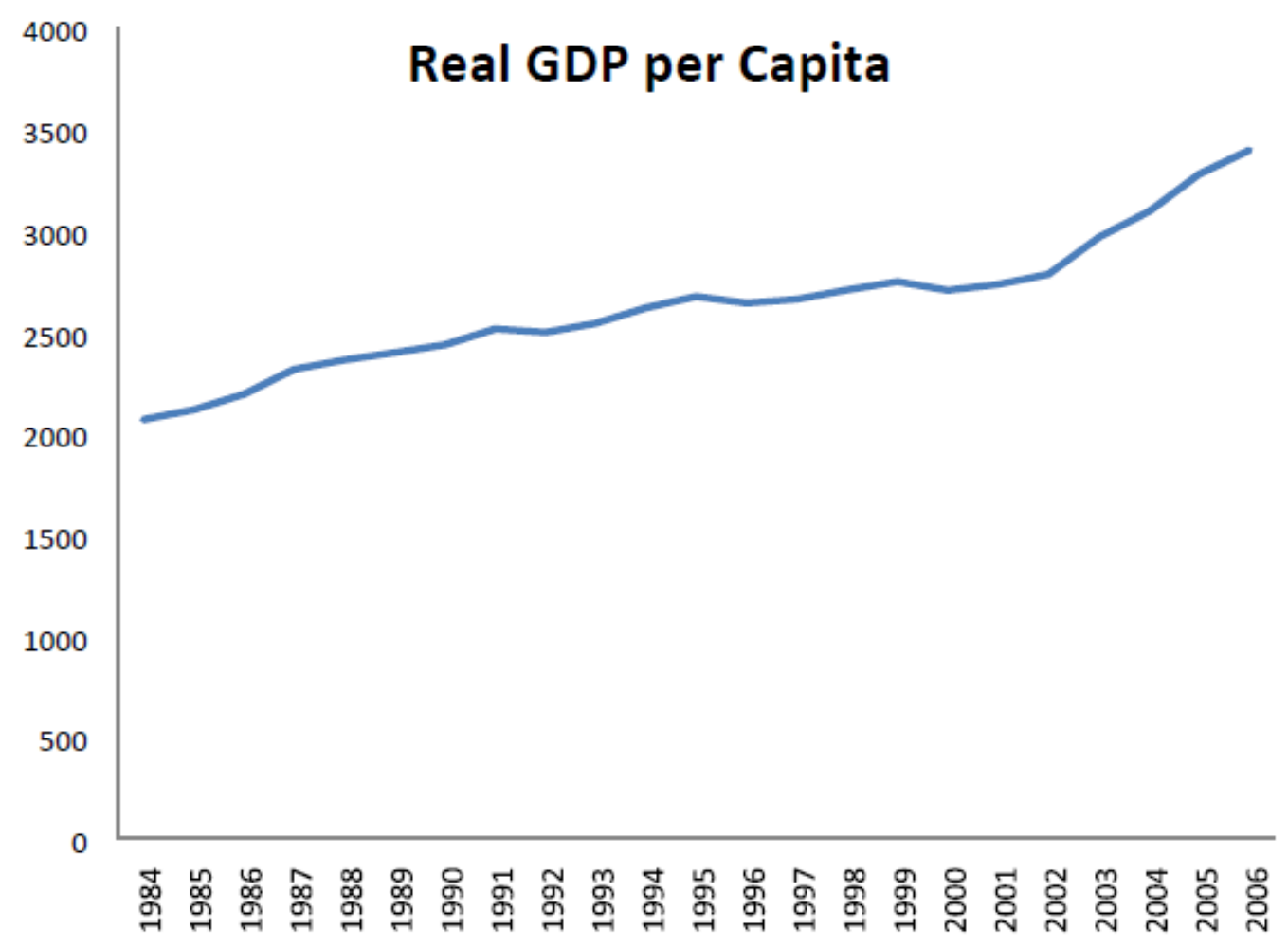

Figure 2. Real gdp per capita 


\section{The Model and Econometric Techniques and Data Description}

\subsection{Model Specification and Data Description}

To explore the causality between Institutions and Growth, we use the following model

$$
y_{t}=\beta_{0}+\beta_{1} I_{t}+\beta_{2} p_{t}+\beta_{2} O_{t}+\epsilon_{t}
$$

where $y_{t}$ is real output in year $t, I_{t}$ is a measure of institutional quality, $p_{t}$ it is inflation, $O_{t}$ is openness measured by total trade to GDP and $\epsilon_{t}$ is an error term. Since the direction of causality is not clear we also specify the model

$$
I_{t}=\beta_{0}+\beta_{1} y_{t}+\beta_{2} p_{t}+\beta_{2} O_{t}+\epsilon_{t}
$$

Both equations are to be considered as long run, or equilibrium relations. We may, of course, have more cointegrating relations involving inflation or trade share as the dependent variable. Provided all variables involved are integrated of order one, or I(1), valid economic inferences can be drawn only if these relations (or perhaps more, having investment share or inflation as dependent variable) are cointegrating relations, otherwise spurious inferences would result. Regarding the data, we use Real GDP per capita in real term as a measure of economic growth. For the institutional variables we have used recently developed indices by Siddiqui and Ahmed (Unpublished) for the measure of institutional quality. We take index of institutionalized social technology, as well as its sub indices of Risk reducing technologies and Anti-rent seeking technologies for measurement of institutional quality. This index and its sub indices are build on theoretical framework of contract and predatory theories set by North. Specifically sub index of Risk reducing technologies is based on contract theory whereas index of Anti-Rent seeking technologies is based on predatory theory of state. These indices are in 0 to 1 ranges where higher values indicating better institutional quality. By the nature of this construction, these variables are bounded above and below by random numbers, which makes it impossible for the series to be non-stationary. Thus, we transform the index using inverse logit function to allow it to vary without limit. Inflation rate is measured using the consumer price index. Whereas Trade share in GDP is Total trade (Exports plus Imports) as a percentage of GDP. Income and trade data are taken from Heston and Summers (2009) whereas Inflation, are taken from World Development Indicators. Table 2 gives detailed information about the variables and their data source whereas descriptive statistics of variables used are given in Table 3.

\begin{tabular}{|c|c|c|c|c|}
\hline & $\begin{array}{c}\text { Variable } \\
\text { Name }\end{array}$ & Description & & Source \\
\hline 1 & RGDPPC & $\begin{array}{c}\text { Real GDP per capita at constant price } \\
\text { (Laspeyres) }\end{array}$ & initial Factor & $\begin{array}{l}\text { Heston and Summers } \\
\qquad(2009)\end{array}$ \\
\hline 2 & INFCPI & Inflation, consumer prices (annual \%) & $\begin{array}{l}\text { Macroeconomic } \\
\text { Stability }\end{array}$ & $\begin{array}{l}\text { World Development } \\
\text { Indicators, World Bank }\end{array}$ \\
\hline 3 & OPEN & $\begin{array}{c}\text { Total trade (Exports plus Imports) as a } \\
\text { percentage of GDP. (export, import and GDP }\end{array}$ & Openness & $\begin{array}{l}\text { Heston and Summers } \\
\qquad(2009)\end{array}$ \\
\hline
\end{tabular}

Table 2. Data sources and description 
figures are expressed in real values)

4 IIST Index Institutionalized Social Technologies $\quad \begin{array}{cc}\text { Institutions } & \begin{array}{c}\text { Siddiqui and Ahmed } \\ \text { (unpublished) }\end{array}\end{array}$

Table 3. Descriptive statistics

\begin{tabular}{|c|c|c|c|c|}
\hline & RGDPPC & IIST & WINFCPI & OPEN \\
\hline Mean & 2619.487 & 0.5122 & 7.4730 & 30.0948 \\
\hline Median & 2632.580 & 0.4906 & 7.8443 & 29.5600 \\
\hline Maximum & 3388.570 & 0.7395 & 12.3682 & 38.6100 \\
\hline Minimum & 2058.170 & 0.2741 & 2.9141 & 26.3000 \\
\hline Std. Dev. & 335.2862 & 0.1050 & 3.1318 & 3.1742 \\
\hline Skewness & 0.5038 & 0.2035 & 0.0319 & 1.1306 \\
\hline Kurtosis & 3.0544 & 3.0077 & 1.7241 & 3.8064 \\
\hline Jarque-Bera & 0.9759 & 0.1589 & 1.5639 & 5.5235 \\
\hline Probability & 0.6139 & 0.9236 & 0.4575 & 0.0632 \\
\hline Sum & 60248.1900 & 11.7809 & 171.8781 & 692.1800 \\
\hline Sum Sq. Dev. & 2473170 & 0.2426 & 215.7741 & 221.6568 \\
\hline Observations & 23.0000 & 23.0000 & 23.0000 & 23.0000 \\
\hline
\end{tabular}

\subsection{Econometric Methodology}

The following sequential procedure will be adopted. Step 1: Unit root test and order of integration we have used Augmented Dickey Fuller (ADF) test to test the stationarity of variables. For time series data, ADF test is a test for unit root. Strong negative numbers of unit root has rejected the null hypothesis that there is unit root at some level of confidence. Following equation check the stationarity of time series data used in the study:

$$
\Delta y=\beta_{0}+\beta_{1} t+\Phi y_{t-1}+\alpha_{i} \Sigma \Delta y_{t-1}+\epsilon_{t}
$$

Where $\epsilon_{t}$ is white noise error term,

These tests have determined that whether the estimates of $\Phi$ are equal to zero or not. Dickey and Fuller (1979) provided cumulative distribution of the ADF statistics by showing that if the calculate-ratio (value) of the coefficient is less than critical value from Fuller table, then $y$ is said to be stationary. However, this test is not reliable for small sample data set due to its size and power properties (Dejong et al., 1992 \& Harris, 2003). For small sample data set, these tests seem to over-reject the null hypotheses when it is true and accept it when it is false. Two new tests, i.e., Dicky-Fuller Generalized Least Square (DF-GLS) and Ng-Perron could solve the problems of data size and power properties. 
Step 2: Cointegration Analysis

The second step is to identify whether all the variables that are included in the system are cointegrated, i.e. tied in a long run relationship. A widely used approach is Johansen's (1988) and Johansen and Jesulius (1990) procedure based on, Maximum Likelihood method and "eigen value statistics" to confirm the existence of long run relationship among all tested variables. Cointegration is said to exist if the values of computed statistics are significantly different from zero. Thus, variables if found to be cointegrated, implies that there exist a linear, stable and long-run relationship among variables, such that the disequilibrium errors would tend to fluctuate around zero mean. This means that variables tend to move together to its steady state path in the long run.

\section{Step 3: Vector Error-Correction Modeling (VECM)}

If a number of variables are found to be cointegrated with at least one cointegrating vector, then there always exists a corresponding error-correction representation which implies that changes in the dependent variable can be formulated as a function of the level disequilibrium in the cointegration relationship and fluctuation in other explanatory variables. In other words the error-correction term in the VECM provides additional channel for the detection of Granger causality. Thus third stage includes conducting standard Granger causality tests augmented with a lagged error-correction term. The Granger (1986) (1988) representation theorem suggests that there will be Granger causality either unidirectional or bi-directional in at least one direction if there exists co-integration relationship among the variables provided the variables are integrated order of one. Engle-Granger (1987) cautioned that if the Granger causality test is conducted at first difference through vector auto regression (VAR) method than it will be misleading in the presence of co-integration. Therefore, an inclusion of an additional variable to the VAR method such as the error-correction term would help us to capture the long-run relationship. The residuals from the long run estimates can be used as the error correction term (ECT) to explain the short run dynamic.

The error correction model representation of the Granger causality model is given in following equations.

$$
\begin{gathered}
\Delta y t=c+\sum \theta i \Delta y t-i+\sum \beta i \Delta I t-i+\sum \Phi i \Delta p t-i+\sum \alpha i \Delta O t-i+\lambda(y t-1-I t-1-p t-1-i \Delta p t-i \text { Ot-i }) \\
+\epsilon t
\end{gathered}
$$

Where $\boldsymbol{\Delta}$ is a difference operator, $\lambda$ representing the coefficient error-correction term derived from long-run co-integrating relationship, $\boldsymbol{c}$ is constant and $\boldsymbol{\epsilon}_{\boldsymbol{t}}$ are serially uncorrelated random disturbance term with zero mean. Through the ECT, the VECM provide new directions for Granger causality to appear. Long-run causality can be revealed through the significance of the lagged ECTS by t test since it contains long-run cointegration information between the variables, because it is derived from the long-term cointegration relationship(s), while F-statistic or Wald test investigate short-run causality through the significance of joint test with an application of sum of lags of explanatory variables in the model. The nonsignificance of both the t-and F-test in the system indicates econometric exogeneity of dependent variable. The purpose of the VECM is to focus on the short run dynamics while 
making them consistent with long run solution.

\section{Empirical Results and Analysis}

The Johansen co-integration method and vector error-correction model technique has been used in order to examine the long run and the short run dynamic of system respectively (Note 1). Prior to testing the long run co-integration relation, it is necessary to establish the order of integration presented. To this end, an Augmented Dickey Fuller (ADF) test with the null hypothesis of unit root, was carried out on the time series levels and difference forms. The critical value for this test is provided by MacKinnon (1991).

The results are given in Table 4 and as this table shows, all the variables have a unit root in their levels and are stationary in their first difference.

Table 4. Unit root estimation (Augmented Dickey Fuller (ADF))

\begin{tabular}{llllllllll}
\hline & \multicolumn{1}{l}{ No Trend } & \multicolumn{4}{c}{ Trend } \\
\cline { 2 - 9 } Variables & LEVEL & \multicolumn{2}{c}{ FIRST DIFFERENCE } & LEVEL & \multicolumn{3}{c}{ FIRST DIFFERENCE } \\
& t-Statistic & lag & t-Statistic & lag & t-Statistic & lag & t-Statistic & lag \\
IIST & -2.447474 & 1 & $(-3.896221)^{* * *}$ & 1 & -2.487936 & 1 & $(-3.842135)^{* *}$ & 1 \\
rgdppc & 1.484928 & 0 & $(-5.016628)^{* * *}$ & 0 & -2.451442 & 2 & $(-5.18409)^{* * *}$ & 0 \\
infcpi & $(-3.809795)^{* * *}$ & 1 & $(-5.967625)^{* * *}$ & 0 & $(-3.741659)^{* *}$ & 1 & $(-5.927934)^{* * *}$ & 0 \\
Open & -1.033062 & 0 & $(-4.698918)^{* * *}$ & 0 & -2.026745 & 0 & $(-4.586755)^{* * *}$ & 0 \\
\hline
\end{tabular}

*MacKinnon (1991) one -sided test.

The lag order has been selected based on Schwarz Information Criterion. Then we explored the stationarity evidence of DF-GLS, and Ng-Perron test statistics. DF-GLS and Ng-Perron are more power full and suggestive tests than

ADF test as already been explained in theoretical background. The statistics are given in Table 5 and 6 . As it shows, institution variable in stationary at level, but when trend is included it becomes stationary at first difference. Rest of the variable also become stationary at first difference. Hence we can safely conclude the presence of unit root and stationarity of the first differences; Thus these variables are integrated of order one I(1). 
Table 5. Unit root estimation (Dicky Fuller GLS(ERS))

\begin{tabular}{lllllllll}
\hline \multirow{2}{*}{ Variables } & \multicolumn{1}{l}{ No Trend } & \multicolumn{7}{c}{ Trend } \\
\cline { 2 - 10 } & LEVEL & & 1st Difference & & LEVEL & \multicolumn{2}{l}{ 1st Difference } \\
\cline { 2 - 10 } & t-Statistic & Lag & t-Statistic & Lag & t-Statistic & lag & t-Statistic & Lag \\
\hline IIST & $(-2.003690)^{* *}$ & 1 & -1.078435 & 2 & -2.416822 & 1 & $(-3.592467)^{* * *}$ & 1 \\
\hline Rgdppc & 1.039024 & 2 & $(-2.67745)^{* * *}$ & 1 & -2.451442 & 2 & $(-5.18409)^{* * *}$ & 0 \\
\hline Infcpi & -1.320502 & 5 & $(-2.562337)^{* *}$ & 5 & -2.850557 & 0 & $(-5.952165)^{* * *}$ & 0 \\
\hline Open & -0.998304 & 0 & $(-4.584298)^{* * *}$ & 0 & -2.191557 & 0 & $(-4.840034)^{* * *}$ & 0 \\
\hline
\end{tabular}

*MacKinnon (1991)

The optimal lags for conducting the test were determined by SIC (Schwarz information criteria).

Null Hypothesis: has a unit root.

Table 6. Unit root estimation (Ng-Perron test)

\begin{tabular}{|c|c|c|c|c|c|c|c|c|c|c|}
\hline \multirow{3}{*}{ Variables } & \multicolumn{9}{|c|}{ No Trend } & \\
\hline & \multicolumn{5}{|l|}{ LEVEL } & \multicolumn{5}{|c|}{ FIRST DIFFERENCE } \\
\hline & MZa & MZt & MSB & MPT & LAG(SIC) & MZa & MZt & MSB & MPT & LAG(SIC) \\
\hline IIST & $(-6.21988)^{*}$ & $(-1.75940)^{*}$ & 0.28287 & $(3.95179)^{*}$ & 1 & -2.13126 & -1.02687 & 0.48182 & 11.4451 & 2 \\
\hline rgdppc & 0.56815 & 0.2691 & \multicolumn{3}{|c|}{$(0.47363)^{* * *}(19.5896)^{* * * 2}$} & \multicolumn{5}{|c|}{$(-20.8428)^{* * *}(-3.14566) * * *(0.15092) * * *(1.46188) * * * 0$} \\
\hline infcpi & $(-10.0383)^{* *}$ & $*(-2.22875)^{* *}$ & $(0.22203)^{* *}$ & $(2.48616)^{* *}$ & 0 & $(-21.545)^{* * *}$ & $(-3.28202)^{* * *}$ & $*(0.15233)^{* * *}$ & $*(1.13761)^{* * *}$ & *0 \\
\hline open & -2.39524 & -0.76641 & $(0.31997)^{* * *}$ & $*(8.42842)^{* * *}$ & & $(-10.4354)^{* *}$ & $(-2.19724)^{* *}$ & $(0.21056)^{* *}$ & $(2.67157)^{* *}$ & 0 \\
\hline \multicolumn{11}{|c|}{ Trend } \\
\hline Variables & LEVEL & & \multicolumn{8}{|c|}{ FIRST DIFFERENCE } \\
\hline & MZa & MZt & MSB & MPT & LAG(SIC) & MZa & MZt & MSB & MPT & LAG(SIC) \\
\hline IIST & -8.069 & -2.00342 & 0.24829 & 11.3065 & 1 & $(-15.5511)^{* *}$ & $(-2.75605)^{* *}$ & $(0.17723)^{*}$ & $(6.04418)^{*}$ & 1 \\
\hline rgdppc & $(-73.326)^{* * *}$ & $*(-5.92471) * * *$ & $*(0.0808)^{* * *}$ & $(1.79406)^{* * *}$ & *2 2 & $(-21.4138)^{* *}$ & $(-3.25058)^{* *}$ & $(0.1518)^{* * *}$ & $(4.38586)^{* *}$ & 0 \\
\hline infcpi & -11.567 & -2.40167 & 0.20763 & 7.89492 & 0 & $(-21.7168)^{* *}$ & $(-3.29231)^{* *}$ & $(0.1516)^{* *}$ & $(4.21364)^{* *}$ & 0 \\
\hline open & -6.91945 & -1.79855 & 0.25993 & 13.2149 & 0 & -10.2728 & -2.13967 & 0.20828 & 9.4107 & 0 \\
\hline
\end{tabular}

The optimal lags for conducting the test were determined by SIC (Schwarz information criteria).

Null Hypothesis: has a unit root

Spectral Estimation Method: GLS-detrended AR.

Given the common integration properties of variables under consideration the next stage to test the presence of multilevel cointegration in the multi dimensional VAR model (RGDPPC, IIST, INFCPI and OPEN) by employing the Johansen (1988) and Johansen and Juselius (1990) procedure using the trace statistic and maximal eigenvalue test. The results of the cointegration tests are given in Table 7 . There is evidence that the results are often sensitive 
to choice of lag lengths. In literature there exist a number of suggested methods for choosing the lag orders. Here an Akaike information criterion table 8 has been used. This suggests two lags of each variable.

Table 7. Johansen's Test For Multiple Cointegration Vectors

\begin{tabular}{|c|c|c|c|c|c|}
\hline $\begin{array}{c}\text { Null } \\
\text { Hypothesis }\end{array}$ & Lag & Eigenvalue & $\begin{array}{c}\text { Trace } \\
\text { Statistic }()^{1}\end{array}$ & $\begin{array}{l}\text { Max-Eigen } \\
\text { Statistic }()^{1}\end{array}$ & $\begin{array}{c}\text { Result at } 5 \% \text { level of } \\
\text { both statistics }\end{array}$ \\
\hline $\mathrm{r}=0^{*}$ & 2 & 0.904324 & $(97.11535)^{* * *}$ & $(46.93567)^{* * *}$ & co-integrated \\
\hline $\mathrm{r} \leq 1^{*}$ & 2 & 0.74257 & $(50.17968)^{* * *}$ & $(27.14016)^{* * *}$ & co-integrated \\
\hline$r \leq 2$ & 2 & 0.507191 & $(23.03952)^{* * *}$ & $(14.15267)^{*}$ & not co-integrated \\
\hline $\mathrm{r} \leq 3^{*}$ & 2 & 0.358755 & $(8.886859)^{* * *}$ & $(8.886859)^{* * *}$ & co-integrated \\
\hline
\end{tabular}

* denotes rejection of the hypothesis at the 0.05 level and both tests

${ }^{1}$ MacKinnon-Haug-Michelis (1999) p-values

Table 8. Lag order selection criteria for VAR

\begin{tabular}{lll}
\hline $\mathrm{K}$ & 1 & 2 \\
\hline Log likelihood & -113.7897 & -85.81825 \\
Akaike information criterion & 13.50379 & 12.98183 \\
Schwarz criterion & 14.89648 & 15.17244 \\
\hline
\end{tabular}

The $\lambda$ trace statistic indicating that there exist four cointegrating vector, with null hypothesis of no, one, two and three cointegration among the variables, the trace statistic cointegrating vector exceeds the 99 per cent critical value of the $\lambda$ trace statistic (critical value is 30.45 ), it is possible to reject the null hypothesis, in the favour of the general alternative $r \geq 3$ (Table 6). Similarly, On the other hand, $\lambda \max$ statistic reject the null hypothesis as the calculated value $\lambda \max$ in null hypotheses of no, one and three conintegration exceeds the 99 per cent critical value (23.65). $\lambda$ max in null hypotheses of two cointegration exceed 90 per cent critical value. The finding of cointegration has several implications. First, the presence of cointegration vectors shows that there exists a long run relationship between the variables. Second, this evidence of cointegration between these variables rules out spurious correlations and also implies at least one direction of Granger causality. The Normalized Cointegration vector in Table 9 indicates that there is a long run positive relationship between institutions and growth. Also there is a positive relationship between openness and growth, and negative relationship between inflation and growth as expected. 
Table 9. Normalized Co-integration vector

\begin{tabular}{lllll}
\hline RGDPPC & C & IISTt-1 & INFCPI $_{\mathrm{t}-1}$ & OPENt-1 \\
\hline 1 & 4504.567 & -1830.188 & 110.5259 & -226.5489 \\
& & $(-0.85794)$ & $(8.72397)^{* * *}$ & $(-13.2214)^{* * *}$ \\
\hline
\end{tabular}

t-stats in parentheses $* * *$ significant at $1 \%$ level.

Regression analysis deals with dependence of one variable on the other variables; it does not necessarily imply causation. In other words existence of a relationship between variables does not prove causality or direction of influence. Engle and Granger (1987) demonstrated that once a number of variables are found to be cointegrated, there always exists a corresponding error correction representation which implies that changes in the dependent variable are a function of level of disequilibrium in the cointegration relation (capture by the error-correction model) specifies that the first differences of all I(1) variables are function of the lagged differences of all these terms in addition to lagged equilibrium error terms. In this respect, since the error-correction term is stationary, all variables in this model are also stationery. This implies that OLS standard errors will also consistent and efficient.

Table 10. Vector error correction models

\begin{tabular}{lll}
\hline Dependent Variable & $\Delta$ RGDPPC (Eq. 1) & $\Delta$ IIST (Eq. 2) \\
\hline Independent Variables & Coeficients, (t-Statistics in paranthesis) \\
ECT t-1 & -0.20042 & $1.54 \mathrm{E}-05$ \\
& {$[-7.08614]^{* * *}$} & {$[0.89197]$} \\
$\Delta \mathrm{RGDPPC}_{\mathrm{t}-1}$ & -0.133217 & 0.0000436 \\
& {$[-0.84784]$} & {$[0.45390]$} \\
$\Delta \mathrm{RGDPPC}_{\mathrm{t}-2}$ & 0.124019 & 0.0000695 \\
& {$[0.65149]$} & {$[0.59693]$} \\
$\Delta \mathrm{IIST}_{\mathrm{t}-1}$ & -650.6761 & 0.353231 \\
$\Delta \mathrm{IIST}_{\mathrm{t}-2}$ & {$[-1.23986]$} & {$[1.10063]$} \\
& 646.2234 & -0.000614 \\
$\Delta \mathrm{INFCPI}_{\mathrm{t}-1}$ & {$[1.65096]$} & {$[-0.00256]$} \\
$\Delta \mathrm{INFCPI}_{\mathrm{t}-2}$ & 14.76375 & 0.000721 \\
& {$[3.09334]^{* *}$} & {$[0.24702]$} \\
& 5.739393 & -0.005459 \\
& {$[1.35058]$} & {$[-2.10060]^{*}$} \\
\hline
\end{tabular}




$\begin{array}{lll}\Delta \mathrm{OPEN}_{\mathrm{t}-1} & -36.93979 & 0.00376 \\ & {[-4.49780]^{* * *}} & {[0.74861]} \\ \Delta \mathrm{OPEN}_{\mathrm{t}-2} & -28.09337 & 0.008295 \\ & {[-4.46130]^{* * *}} & {[2.15413]^{*}} \\ \mathrm{C} & 91.78006 & -0.012028 \\ & {[6.44991]^{* * *}} & {[-1.38223]} \\ \text { R-squared } & 0.8945390 .799623 & 0.5402160 .1264111 .305483 \\ \text { Adj. R-squared } & 9.424608 & 60.06964 \\ \text { F-statistic } & -87.92084 & -5.006964 \\ \text { Log likelihood } & 9.79208410 .28995 & -4.509097 \\ \text { Akaike AIC } & 2.324982 & 1.635949 \\ \text { Schwarz SC } & & \\ \text { Durbin-Watson stat } & & \end{array}$

From the estimated results reported in Table 10, it is evident from the table that error correction term is only significant in equation (1). So Institutional quality Granger causes growth in the long run. The error correction term is not significant in equation (2). Thus, Growth does not cause institutional quality in long run. The results indicate that the long run causality between growth and institutions is uni-directional: There is only one-way long run causality from institutions to growth; however, no long run causality, in the Granger sense, was found in opposite direction. This indicates that institutions causes economic growth in Pakistan.

To determine the dunamics of shrot run causality, we took F-statistic or Wald test of sum of lags of explanatory variables in the model. The results of bivariate Granger causality tests are in Table 11.

Table 11. Summary of Bi-variate Granger causality tests

\begin{tabular}{|c|c|c|c|c|c|}
\hline \multirow{2}{*}{$\begin{array}{l}\text { Dependent } \\
\text { Variable }\end{array}$} & & \multicolumn{2}{|l|}{ F Statistics } & \multicolumn{2}{|c|}{ Coeficient and t-Statistics } \\
\hline & $\Delta \mathrm{YRGDPPC}_{\mathrm{t}-\mathrm{n}}$ & $\Delta \mathrm{IIST}_{\mathrm{t}-\mathrm{n}}$ & & ECTt-1 & \\
\hline \multicolumn{6}{|l|}{$\Delta$} \\
\hline YGDPPC2 & - & 1.716399 & $(50.21337)^{* * *}$ & -0.201146 & {$[-7.05326]^{* * *}$} \\
\hline$\Delta$ IIST & 0.395241 & - & 0.795603 & 0.000066 & {$[0.87015]$} \\
\hline
\end{tabular}

The estimated F Statistics of joint test shows that lags of Institutions are insignificant in growth equation (1) equation and lags of growth are also insignificant in institutions equation (2). Thus there is no short run causality from institutions to growth and vice versa. 
Table 12. Diagnostic tests

\begin{tabular}{lll}
\hline VEC Models & E(1) & E(2) \\
& $\Delta$ GDPPC & $\Delta$ IIST \\
\hline Functional Form $^{1}$ & $0.352350(0.5674)$ & $1.185570(0.3045)$ \\
Autocorrelation $^{2}$ & $5.503359(0.3201)$ & $0.437426(0.8352)$ \\
Normality $^{3}$ & $1.197621(0.549465)$ & $0.886806(0.641848)$ \\
Heteroskedasticity $^{4}$ & $1.890833(0.1675)$ & $1.322892(0.3331)$ \\
\hline
\end{tabular}

${ }^{1}$ Ramsey RESET Test

${ }^{2}$ Breusch-Godfrey Serial Correlation LM (langrene Multiplyer) Test Fstatistic (for the joint significance of all lagged residuals) with 9 lag inclusion based on AIC

${ }^{3}$ Jarque-Bera(JB) Residual Normality Tests.

${ }^{4}$ Breusch-Pagan-Godfrey test.

Diagnostic tests for serial correlation, heteroscedisticity and functional form are conducted and the results are shown in Table 12. These tests show that short run model passes through all diagnostic tests. The results also indicated that there is no evidence of serial correlation among variables because functional form of model is well specified and there is no evidence for white heteroscedisticity as in each case the null hypothesis could not be rejected at conventional 5\% level of significance, implying thereby that our results are statistically free from any specification problems.

\section{Conclusion}

In this paper, we have examined the question of whether Quality of institutions, Grangercause economic growth or vice versa. This paper has examined the long run relationship between institutions and growth in Pakistan using annual data for the period 1984-2006. The empirical investigation consists of: (1) the application of cointegration analysis to ascertain the long run relationship between institutions and growth (2) the determination of the direction of causality among the variables in the context of vector error correction model. Our results indicate that institutions and growth are cointegrated and thus exhibit a reliable long run relationship. The results indicate that the causality between institutions and growth is uni-directional: There is only one-way long run causality from institutions to growth; however, no long run causality, in the Granger sense, was found in opposite direction. Similarly, there is no short run causality from institutions to growth and vice versa. The most important implication of our findings is a policy recommendation: If policy makers want to promote growth, then attention should be focused on long run policies, for example the creation of sound political and social institutions that minimize rent seeking opportunities and reduce risk of doing businesses. However its positive impact could be felt in long run, as in short run, it could cause adverse impact in form of curbing opportunities of rent seekers.

However the notion of increased economic growth would lead to strong institutions in long run cannot be accepted. Hence sustainable growth could only occur in the ambit of sound 
social and political institutions. As in their absence, even best policies for development and attracting investment might fail as no incentive can balance the huge business risk that could arise if property rights are not secured and contract enforcement is week. Also menses of corruption and nepotism divert any policy incentives given to entrepreneurs towards rent seekers making economy stuck in structural rigidities making any policy ineffective.

\section{References}

Acemoglu, D., Johnson, S., \& Robinson, J. A. (2001). The Colonial Origins of Comparative Development: An Empirical Investigation. American Economic Review, 91, 1369-1401. https://doi.org/10.1257/aer.91.5.1369

Acemoglu, D., Johnson, S., \& Robinson J. A. (2002). Reversal of Fortune: Geography and Institution in the Making of the Modern World Income Distribution. Quarterly Journal of Economics, 117, 1231-1294. https://doi.org/10.1162/003355302320935025

Acemoglu, D., Johnson, S., \& Robinson, J. A. (2005). Institutions as the Fundamental Cause of Long-Run Growth. Handbook of Economic Growth. https://doi.org/10.1016/S15740684(05)01006-3

Acemoglu, D., \& Johnson, S. (2005). Unbundling Institutions. Journal of Political Economy, 113, 949-95. https://doi.org/10.1086/432166

Ahmed, S. (2001). Poverty Reduction and Governance in South Asia. Mahbub ul Haq Human Development Review, 1(1).

Barro, R. J. (1997). Determinants of economic growth: a cross-country empirical study. Development Discussion Paper No. 579, Harvard Institute for International Development.

Barro, R. J. (2000). Inequality and growth in a panel of countries. Journal of Economic growth, 5(1), 5-32. https://doi.org/10.1023/A:1009850119329

Dejong, D. N., Nankervis, J. C., \& Savin, N. E. (1992). Integration Versus Trend Stationarity in Time Series. Econometrica, 60, 423-33. https://doi.org/10.2307/2951602

Dickey, D., \& Fuller, W. A. (1979). Distribution of the Estimates for Autoregressive Time Series with Unit Root. Journal of the American Statistical Association, 74, 427-31. https://doi.org/10.1080/01621459.1979.10482531

DRI/McGraw-Hill. (1998). An Agenda for Effective Governance. Enterprise 2010: Realising Pakistan's Full Potential. Lexington, MA: DRI/McGraw-Hil.

Easterly, W. (2003). The Political Economy of Growth Without Development: A Case Study of Pakistan. In Search of Prosperity: Analytical Narratives of Growth. Princeton University Press. https://doi.org/10.1515/9781400845897-016

Easterly, W., \& Levine, R. (2002). Tropics, Germs, and Crops: How Endowments Influence Economic Development. Centre for Global Development and Institute for International Economics. https://doi.org/10.3386/w9106

Engle \& Granger, C. (1987). Cointegration and Error correction: Representation, Estimation and Testing. Econometrica, 55, 251-76. https://doi.org/10.2307/1913236

Fernandes, A. M., \& Aart, K. (2007). Property Rights Institutions, Contracting Institutions, and Growth in South Asia: Macro and Micro Evidence. New Delhi: MACMILLAN

Frye, T., \& Shleifer, A. (1997). The Invisible Hand and the Grabbing Hand. American 
Economic Review Papers and Proceedings, 87, 354-58.

Gelos, G., \& Shang-Jin, W. (2002). Transparency and International Investor Behavior. NBER Working Paper No. 9260, 1-36. https://doi.org/10.3386/w9260

Granger, C. W. J. (1986). Developments in the Study of Cointegrated Economic Variables. Oxford Bulletin of Economics and Statistics, 48, 213-228. https://doi.org/10.1111/j.1468-0084. 1986.mp48003002.x

Granger, C. W. J. (1988). Some Recent Developments in a Concept of Causality. Journal of Econometrics, 39, 199-211. https://doi.org/10.1016/0304-4076(88)90045-0

Haq, R., \& Zia, U. (2009). Does Governance Contribute to Pro-poor Growth? Evidence from Pakistan. PIDE Working Papers. Islamabad:Institute of Development Economic.

Harris, R., \& Sollis, R. (2003). Applied Time Series Modeling and Forecasting. West Sussex: Wiley.

Hassan, M. T. (2002). Governance and Poverty in Pakistan. MIMAP Technical Series, No.13, Pakistan Institute of Development Economics. Islamabad.

Heston, A., Summers, R., \& Aten, B. (2009). Penn World Table Version 6.3. Center for International Comparisons of Production, Income and Prices at the University of Pennsylvania.

Hussain, I. (1999). Pakistan: The Economy of an Elitist State. Karachi: Oxford University Press.

Jalilian, H., Kirkpatrick, C., \& Parker, D. (2007). The Impact of Regulation on Economic Growth in Developing Countries: A Cross-Country Analysis." World Development, 35(1), 87-103. https://doi.org/10.1016/j.worlddev.2006.09.005

Johansen, S. (1988). Statistical Analysis of Cointegrating Vectors. Journal of Economics Dynamics and Control, 12(2), 231-54. https://doi.org/10.1016/0165-1889(88)90041-3

Johansen, S., \& Juselius. (1990). Maximum Likelihood Estimation and Inference on Cointegration With Applications the Demand for Money. Oxford Bulletin of Economics and Statistics, 52(2), 169-210. https://doi.org/10.1111/j.1468-0084.1990.mp52002003.x

Johnson, S., Kaufmann, D., \& Zoido-Lobaton, P. (1998). Government in Transition: Regulatory Discretion and the Unofficial Economy. The American Economic Review, 88, 387-392.

Kauffman, D., Kraay, A., \& Mastruzzi, M. (2005). Governance matters IV: Governance indicators for 1996-2004. World Bank Policy Research, May. https://doi.org/10.1596/18139450-3630

Kauffman, D., \& Kraay, A. (2002). Growth without governance. Mimeo, Washington, DC: World Bank.

Kirkpatrick C., Parker, D., \& Zhang, Y. (2006). Foreign direct investment in infrastructure: Does regulation make a difference? Transnational Corporations, 15(1).

Knack, S., \& Keefer, P. (1995). Institutions and Economic Performance: Cross Country Tests Using Alternative Institutional Measures. Economics and Politics, 7, 207-22. https://doi.org/10.1111/j.1468-0343.1995.tb00111.x

Lucas, R. E. (1988). On mechanism of economic planning. Journal of Monetary Economics, 
21(1), 3-42. https://doi.org/10.1016/0304-3932(88)90168-7

Mackinnon, J. G. (1991). Critical values for Cointegration Tests. In R. F. Engle, \& C. W. J. Granger (Eds.), Long-Run Economic Relationships: Readings in Cointegration. Oxford: Oxford University Press.

MacKinnon, J. G., Alfred, A. H., \& Leo, M. (1999). Numerical Distribution Functions of Likelihood Ratio Tests for Cointegration. Journal of Applied Econometrics, 14, 563-577. https://doi.org/10.1002/(SICI)1099-1255(199909/10)14:5\%3C563::AID-JAE530\%3E3.0.CO; $2-\mathrm{R}$

Mahbub ul Haq Human Development Centre. (1999). Human Development in South Asia: "The Crisis of Governance. Pakistan: Mahbub ul Haq Human Development Centre and the Oxford University Press.

Mauro, P. (1995). Corruption and growth. Quarterly Journal of Economics, 110, 681-712. https://doi.org/10.2307/2946696

Méon, P-G., \& Sekkat, K. (2004). Does the Quality of Institutions Limit the MENA's Integration in the World Economy? The World Economy, 27, 1475-1498. https://doi.org/10. 1111/j.0378-5920.2004.00661.x

Méon, Pe-G., \& Laurent, W. (2006). Does Better Governance Foster Efficiency? An Aggregate Frontier Analysis. Economics of Governance, 6(1), 75-90. https://doi.org/10.1007/ s10101-004-0080-Z

Ng, S., \& Pierre, P. (2001). Lag Length Selection and the Construction of Unit Root Tests with Good Size and Power. Econometrica, 69(6), 1519-1554. https://doi.org/10.1111/14680262.00256

North D. C. (1990). Institutions, institutional change and economic performance. Cambridge, MA: Cambridge University Press, New York. https://doi.org/10.1017/CBO9780511808678

North, D. C. (1981). Structure and Change in Economic history. New York: Norton.

North D. C., \& Thomas, R. P. (1973). The Rise of the Western World. A New Economic History. Cambridge, MA: Cambridge University Press. https://doi.org/10.1017/CBO978051 1819438

Olson, M., Sarna, N., \& Swamy, A. V. (1998). Governance and growth: A simple hypothesis explaining crosscountry differences in productivity. Mimeo: Centre for Institutional Reform and Informal Sector (IRIS), University of Maryland.

Putnam, R. D., Leonardi, R., \& Nanetti, R. Y. (1993). Making Democracy Work: Civic Traditions in Modern Italy. Princeton: Princeton University Press.

Reisen, H., \& Marcelo, S. (2001). Which Types of Capital Inflows Foster Developing-Country Growth? International Finance, 4(1), 1-14.

Rodrik, D., Subramanian, A., \& Trebbi, F. (2004). Institutions rule: the primacy of institutions over geography and integration in economic development. Journal of Economic Growth, 9(2), 131-165. https://doi.org/10.1023/B:JOEG.0000031425.72248.85

Rodrik, D., \& Subramanian, A. (2003). The primacy of institutions. Finance and Development, 40, 31-34.

Romer, P. M. (1986). Increasing returns and long-run growth. Journal of Political Economy, 
94(5), 1002-1037. https://doi.org/10.1086/261420

Sachs, J. D., \& Warner, A. M. (1995). Economic reform and the process of global integration. Brookings Paper in Economic Activities, 1, 1-95. https://doi.org/10.2307/2534573

Schleifer, A., \& Vishney, R. W. (1993). Corruption. Quarterly Journal of Economics, 108, 599-617. https://doi.org/10.2307/2118402

Schleifer, A., \& Vishney, R. W. (1994). Politicians and Firms. Quarterly Journal of Economics, 109, 995-1025. https://doi.org/10.2307/2118354

Shafique, S., \& Haq, R. (2006). Governance and Income Inequality. The Pakistan Development Review, 45(4), 751-760. https://doi.org/10.30541/v45i4IIpp.751-760

Siddiqui, D. A., \& Ahmed, M., Q. Does Institutions effect growth in Pakistan? An Empirical investigation. Unpublished Manuscript.

Smarzynska, B. K., \& Shang-Jin, W. (2000). Corruption and Composition of Foreign Direct Investment: Firm-Level Evidence. NBER Working Paper No. 7969, 1-24. https://doi.org/10.3386/w7969

Solow, R. M. (1956). A contribution to the theory of economic growth. Quarterly Journal of Economics, 70, 65-94. https://doi.org/10.2307/1884513

Soto, H. de. (1989). The Other Path: The Invisible Revolution in the Third World. New York: Harper \& Row Publishers.

Soto. H. de. (2000). The Mystery of Capital: Why Capitalism Triumphs in the West and Fails Everywhere Else. New York: Basic Books.

SPDC Social Policy and Development Centre. (2000). Social Development in PakistanAnnual Review 1999: Towards Poverty Reduction." Karachi: Social Policy and Development Centre and the Oxford University Press.

Tabellini, G. (2005). Culture and Institutions: Economic Development in the Regions of Europe. CESIFO Working Paper no. 1492.

World Bank. (2003). Global economic prospects and the developing countries. Washington, DC: World Bank. https://doi.org/10.1596/0-8213-5582-1

\section{Copyright Disclaimer}

Copyright for this article is retained by the author(s), with first publication rights granted to the journal. This is an open-access article distributed under the terms and conditions of the Creative Commons Attribution license (http://creativecommons.org/licenses/by/3.0/). 